Bu makaleye atıfta bulunmak için/To cite this article:

ALRASHED, E. (2021). The Influence of Translating Foreign Poetry on Modern Arabic Poetry. Atatürk

Üniversitesi Sosyal Bilimler Enstitüsü Dergisi, 25 (Özel Sayı), 353-364.

\title{
The Influence of Translating Foreign Poetry on Modern Arabic Poetry
}

\author{
Eyass ALRASHED ${ }^{(*)}$
}

\begin{abstract}
This research studies the influence of translating foreign poetry on contemporary Arabic poetry since the onset of the Renaissance, till the beginnings of the twentieth century. It also reviews the critics' opinions along the centuries tackling the question of poetry translation, whether it's possible or impossible. Moreover, it observes the poets' contributions which stand for the issue of modernising poetry either through their critical views or their literary topics and presents how their opinions and views have been developed towards the modern poetry. This research tries to understand the development of modern poets' literary taste and the intellectual stimulus to their artistic project since the beginning of the fifties of the twentieth century. It, in addition, highlights the obstacles that the poets faced and what caused to detain their domination on the literary scene and the (return) revival of the traditional poem one more time.

Keywords: Arabic Language and rhetoric, Modern poetry, renaissance, translation, rhythmic poems, semi-rhythmic poems, prosaic poems.
\end{abstract}

\section{Yabancı Șiir Çevirisinin Modern Arap Şiirine Etkisi}

Öz: Bu araştırma Rönesans döneminden başlayıp yirminci yüzyılın başlarına kadar olan dönemde yabancl şiir çevirisinin çağdaş Arap şiirine olan etkisini irdelemektedir. Eleştirmenlerin çağlar boyunca şïr çevirisinin mümkün olup olmadı̆̆ şeklindeki görüşlerini aktarmakta, şiirin yenilenmesi konusundaki kaleme aldıkları ister eleştiri yazıları aracılığılla olsun, ister edebi metinler yoluyla olsun, şairlerin katkılarını ve modern şiir hakkındaki görüşlerinin gelişim sürecini aktarmaktadır. Bu araștırma modernist şairlerin zevklerinin gelișim sürecini anlamaya; sanatsal projelerinin düşünsel tetikleyicisini, yirminci asrın ellili yıllarından itibaren sahada öncü olmalarına yardım eden teşvik edici faktörleri, yollarına çıkıp sahadaki hâkimiyetlerine son veren engelleri ve geleneksel şiirin tekrar dönmesine neden olan etkenleri bulmaya çalışmaktadır.

Anahtar Kelimeler: Arap Dili ve Belâgatı, Modern şiir, Rönesans, çeviri, ölçülü şiir, serbest şiir.

Makale Gelis Tarihi: 03.05.2021

Makale Kabul Tarihi: 25.11.2021

DOI:10.53487/ataunisosbil.932310

\section{Introduction}

The poem renewal of formalisation and content has been the obsession of Arab poets all along centuries. The pace of discussion increases about this issue whenever a condensed contact takes place between the Arab culture and the other neighbouring ones. The battle between the traditional and the contemporary sides which started in the mid of the lunary second century, coincided with the intensive translation movement from

*) Dr. Öğr. Üyesi, Atatürk Üniversitesi İlahiyat Fakültesi Arap Dili ve Belagatı Ana Bilim Dalı (eposta: eyass.alrashed@atauni.edu.tr) (D) ORCID ID. https://orcid.org/0000-0001-7824-8952.

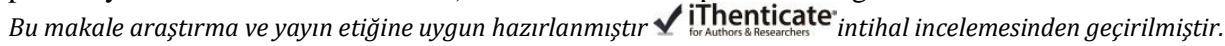


the Arab neighbouring's culture, such as the Greeks, the Persians, the Romans and the Indians. The arrival of Napoleon Bonaparte's military expedition to Egypt has made the Arab culture exposed to a new contact with a foreign culture, especially when Napoleon brought printing machines and some groups of writers and scientists accompanied the military expedition. Later, a deep communication started between the Arab and the west through Muhammad Ali Basha's scholarships, particularly to France. During the beginnings of the twentieth century, the Arab artists where well-exposed to French, English and Italian poetry. They have obtained a deep understanding of the methods where used in the west. Hence, new questions have been raised about the formalisation of the poem and the sacred rhythms and content of Al-Khalil Ibn Ahamd Al-Farahidi (the founder of prosody) that poets used to tackle before.

\section{Translating Poetry in Critical Argumentation}

The issue of translating poetry has occupied people working in literature from an early age and this was one of the controversial issues that accompanied the literary activity of humans. Horace, since the third century BC, rejected in his book "The Art of Poetry" every literal translation as it's one of the characteristics of a weak-hearted translator (Horace, 1988: 118). The shadow of this idea remained constant until it reached the Arabs who kept working on translating the books of philosophy, engineering and medicine from other nations such as India, China, Greece and Rome, keeping in mind that the Greeks' thought had the greatest impact on translation as well as influencing the philosophical, linguistic and critical thinking of the Arabs. For this reason, Al-Jahiz (775-868 AD) has refused to translate poetry saying: "The virtue of poetry is limited to the Arabs and to those who speak the Arabic language, and poetry can't be translated and it's not permissible to be transmitted. If poetry has been transmitted, it would lose its structure, rhythm, beauty and the admiration characteristics which is different from the prosaic texts. In this case the prosaic texts themselves would be better and more credible than another prosaic text that has been translated from rhythmic poetry." (al-Jahiz, 1996: 1/74-75) As a result, Al-Jahiz's previous words lead to spot the light on many issues. First, it's the important status of poetry to the Arabs who believe that they are specifically the nation of poetry and their superiority in poetry is indisputable. Poetry was the greatest record of the Arabs. Therefore, Ibn Sallam AlJumahy (756-845 AD), said: "Poetry, in the pre-Islamic era, was the record of the Arabs' knowledge and the authentic source which they depended on, took from and referred to (Ibn Sallam al-Jumahi, wd: 1/41). Moreover, the Holy Quran has challenged the Arabs to create a single Quranic verse, but they failed. This challenge shows the great importance of poetry in the Arabs' life and when they received the Holy Quran, they claimed that it has been poetry, and that's because they are the masters of this art, in addition, the magical narrative ability of the poet who picks poetry from what is called "Ingenious Valley" (Abkar Valley, the valley of inspiration, the imaginary home of poetry; fairyland), and every poet has his own Jinn who takes inspiration and poetry from. Second, the issue is related to the concept of the poetic language and culture in every language. This matter has also been the focus on discussions and debates since 
Plato who expelled poets out from his Republic (The Republic 375 BC.) passing to Aristotle (384-322 BC.) who believed that poeticism is a simulation. These ideas had a great impact during the establishment of the poetic conception on the Arabic traditional criticism.

We have seen those who were influenced by Plato like Al-Farabi (872-950 AD.) and those influenced by Aristotle like Ibn Sina (Avicenna, 980-1037 AD.) and Ibn Rushd (Averroes, 1126-1198 AD.), and there is another predisposition that confines poetry to the rhythmic speech like Qudama Ibn Ja'far (873-948 AD). Then, the matter was expanded to become a discussion of fiction and imagination as according to Hazem Ibn Muhammad Al-Qartajanni (1211-1386 AD.) and to find ourselves facing a comprehensive vision of the concept of poetry (Nazam Hasan, 1994: 20-32). This understanding to the spirit of poetry i.e what makes speech into poetry according to AlJahiz is the first basis of refusing poetry being translated. When poetry is affected by translation, it would lose its first identity which is rhythm and that's why Al-Jahiz stood against that risk as it would transfer this harmonious and coherent spirit to another strange field. Al-Jahiz has also explained the reason of his rejection based on his understanding of the poetics of the text an he stated four elements of this poetics. First, it's the versification which means the flow of speech according to Al-Khalils' rhythmics poetry that ends up with a rhyme. Second, it's the beauty which is the key of the diction including metaphor, analogy and metonymy. Third, the value of wonder (admiration) which is the audience's receiving and approval to the text and its influence on them. AlJahiz as well believes that translating rhythmic poetry is unacceptable due to the different musical structure in different languages. The Arabs work on the rhythmic musical in accordance to the poetic rhythm, so they re-build what is rhythmic on what is rhythmic. Whereas, foreigners stretch words-worth, so they expand and grab till they form the musical rhythm and in this case they gather what is rhythmic to non-rhythmic. (al-Jahiz, wd: 1/241) Al-Jahiz's belief of translating poetry wasn't based on the superiority of the Arabs in this field only, but his point of view was based on a deep understanding to the foreign poetry and its musical structure and comparing between the music of Arabic poetry and the foreign one, is the best proof of that issue which is reasonable and natural. Al-Jahiz lived in an era of translation boom and undoubtedly he knew other languages than Arabic. This strict stance of translating poetry was not confined to Arab-Islamic culture and Al-Jahiz himself, but that view remained and survived till the modern age and the critical schools have adopted it in the twentieth century, such as structuralism, linguistics and formalism. Jacobson believes that poetry is based on self-referral and the concept of semiotic system. For this reason poetry can't be translated as it would lose its most prominent feature: the poetic function. Jacobson says: "Poetry in accordance to its definitions can't be translated while the only way to be translated is to be creative" (Agina, 2001: 92). Translating poetry has been in the hands of linguistic schools that led the critical scene in the twentieth century. The crisis of translating poetry begins with language because the semantic fields don't match, the structures as well aren't equal, and the statements' styles don't carry the same cultural legacies. This is what, can be said about the edged semi-silent indications that support and enrich the lexical meaning which is more accurate than the original lexicography. It also floats in a certain way among the signs, statements and the short and long syllables. So, through this complex repulsion the 
foreign text takes its resistance against translation which is in this sense declares its scattered incapability of translation (Ricoeur, 2008: 19).

\section{The Influence of Translation on the Arab Modern Poetry}

\section{A. Translations of Arab Classics and Romantics}

The translation of poetry hasn't been paid attention to all the controversy that lasted for a number of years which is similar to what happened in the issue of poetry renewal where battles erupted between critics and poets. The battle ended up with poets kept moving forward indifferently ignoring the warning of critics or their attempt to set methodological frameworks for poetry to follow. Such issues take the most extreme degrees of rebellion as if blame was a temptation in this context. The best example is the issue of modernising poetry at the beginning of the Abbasid era (749-1258 AD.) and the debate that took place between Bashar Ibn Burd, Abu Nuwas and those who are like them, and the conservative critics led by Abu Amr Ibn Al-Alaa and Al-Asma'i. As well as, the battle of renewal of Arabic poetry that took place at the beginning of the twentieth century which was accompanied by a translation activity not witnessed before in the Arab culture since the era of AL-Ma'mun (786-833 AD). Another example, Sulayman Al-Bustani (1856-1925 AD.) translated the Iliad in his own poetic language and Ameen Al-Rihani (1876-1940 AD.) translated the "Leaves of Grass" written by the American poet Walt Whitman which contains poems of free poetry. The term "free poetry" hasn't been used in the Arabs' culture before. In addition, The Diwan School Group, in the first quarter of the twentieth century, carried out a clear translational activity and the Apollo School of Poetry which was founded by Ahmad Zaki Abu Shadi came into existence. Calling that school by this name "Apollo" is a clear indication of the western influence on the minds of those poets who made the romantic poems such as John Keats, Percy Bysshe Shelley, Lord Byron, William Wordsworth and Lamartine are their ideal examples and the contents of romantic poetry have become present in their poetry.

\section{B. The Influence of T.S. Eliot on Contemporary Arabic Poetry}

Above all, the defining moments in the influence of translated poetry on modern Arabic poetry was the influence of T.S. Eliot, especially his two poems: "The Waste Land" and "The Hollow Men". Eliot has relied on myths to write these two poems and what paying more attention is that Eliot has placed footnotes for both poems explaining the myths he used. "The Waste Land" contains lines in different languages, such as Hindi, Spanish, German and French; he has also mobilised and implied different types and colours of knowledge that for the most parts are not within the limits of an ordinary reader's knowledge and culture. Eliots' use of other six languages than English in his poems obliged him to place a lot of footnotes explaining those knowledgable dimensions which he himself has mastered up. For this reason, Eliots' poetry was accused of excessive rationality in addition to ambiguit (al-Qoud, 2002: 25; Luallwa, 1980: 22-23) This is a new heresy in poetry and the semi-rhythmic poets have adopted and learnt that method and represented it when a group of them called themselves "Tammuzian Poets" in regard to the myth of Tammuz, such as Bader Shaker Al-Sayyab, Jabra Ibrahim Jabra, 
Idonis and others. The myth has become a part of the modern poem and those poets had clear models to follow and these models have become mature, keeping in mind that Eliot wrote "The Waste Land" in 1922, in addition to the presence of some models of modern Arabic poetry that followed that approach, such as Abbas Mahmoud Al-Aqqad (18891969 AD.) in his poem "Stories and Lessons" in which he says:

(al-Akkad, 2013: 133)

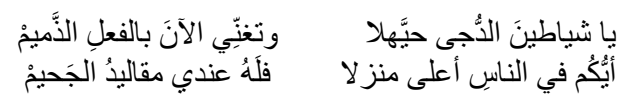

"O' demons of the dark, come alive,

And are now singing unholy deeds

Whoever, is of higher rank

For him, I have the reins of hell"

The critic Maroun Abboud criticised this poem and this method saying: "The poem isn't devoid of sober poetry that makes us forget the dullness of the preceding poor and prosaic philosophy" (Abboud, 2012: 181). Such models where dealing with the myth as a narrative framework and this is not similar to Eliot's project. In this case we have come to be exposed to poems that contain a large pack of Greek mythology, such as Sisyphus and Ulysses, and Babylonian and Aramaic myths. Then, these poems have become a place to review those myths especially when Jabra Ibrahim Jabra translated "The Golden Bough" by James Frazer which includes those myths. This is what caused ambiguity and confusion in the Arabic poem and caused its movement become slow and burdened by these heavy cultural loads which came out of a negative effect. In fact, the poets wanted to use the myths in order to revive the text from the inside and to escape from the monotonous and direct tonality as they claimed, but they encountered a problem with the audience who suffered from the lack of understanding to these texts because the references of the myths are far from their cultural reality and aren't addressing anything in their knowledgable conscience. The poet has been required to explain the myths to the audience in order to reach the essence of the poem. The idea of using the myths as an artistic mask seemed to fall apart because this type of poems have become a strange outgrowth of the audience's reality. And, the poet climbed up to his ivory tower waving his hand away from the audience, asking them to follow him but the truth is that wouldn't happen. Let's have a look at Al-Sayyab's Poem "Cerberus in Babylon":

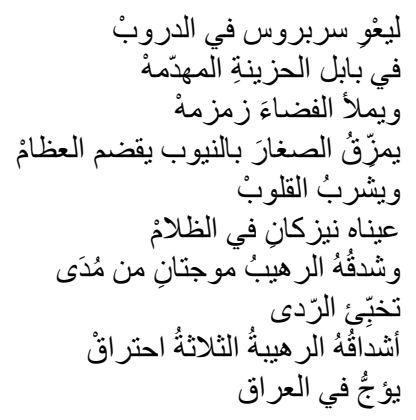




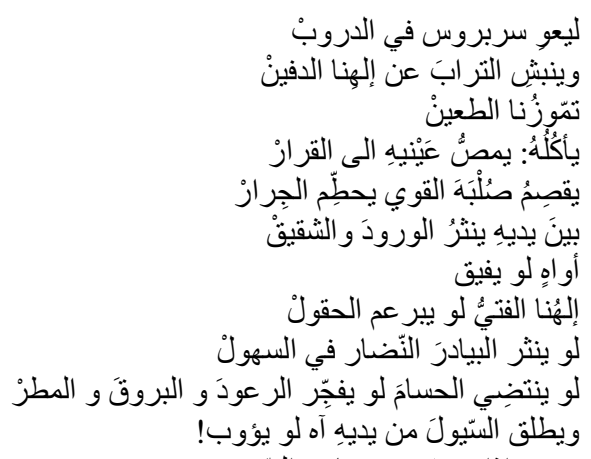

ونحن إذا نبصّ من مغاور السِّنِن. (Al-Sayyab, 2016: 2/125)

"To howl Cerberus in the paths

In the sad, destroyed Babylon

To fill up the space with phonemes

To rupture by fangs, the children

To gnaw the bones, drink the hearts,

Meteors are his eyes in the dark

Two extended waves are his buccleuch,

Hide the death

His three horrible buccleuch, burning

Burst out in Iraq

To howl Cerberus in the paths

Exhume dust from our buried God,

Our lancinating Tammuz, eating

Sucking his eyes, to decide

Breaking his back, destroying the jars

In his hands, spreading the flowers, the brothers

$\mathrm{O}^{\prime}$ if he wakes up

Our young God, would sprout the fields,

If scatters the supple bedders in plains

If holds the sword up

If explodes thunder, lightning and rain

If releases torrents out of his hands,

$\mathrm{O}^{\prime}$ if returns

We look from the caves of the years"

In this poem Al-Sayyab recalls the myth of Cerberus, which is the dog that guards the death kingdom in the Greek mythology, in order to express the reality of Iraq (Babylon) and thus the poem turns into a mythical battleground: its heroes, places, times and events are all legendary. Cerberus, in the legendary meaning is the preceding Iraqi president Abdulkarim Qasim in real and Babylon is the same as Iraq itself. Despite of Al-Sayyab's extravagant in mentioning ancient myths, such as Adonis, Tammuz and Ulysses which need explanation and interpretation in order to hold onto the recipient, his 
poem "The Rain Song" has been very popular and its fame has spread beyond the horizon. It has become one of the archives of those related to and interested in poetry in spite of versifying it according to Al-Rajaz (it's a metre used in classical Arabic poetry) rhythm which is called the poets' donkey. This way of writing was accompanied by a feverish activity to translate collections of poets from most living languages. As a result, we started to read the Spanish Lorca, the Chilean Pablo Neruda, the Russian Pushkin, the Dagestan Rasoul Hamzatov, and the Turkish Nazem Hikmat and so the audience of literature have become face to face with a new poetry far removed from the Arabic poetry which extended since the dawn of the Arabic poetry till the beginning of the twentieth century. Then, the critical battles on rhythm and rhymes have been waned and coincided with the appearance of the semi-rhythmic poetry (form-and-shape shifting poems) that Nazik Al-Malaika and Bader Shaker Al-Sayyab created and they are both regarded as the pioneers of modernist Arabic poetry. Moreover, a magazine in Beirut called "Poetry" started to publish the prosaic poem which is accompanied with critical studies that theorise for this new style of poetry which resembles the western poetry and translated poetry following its form, shape and contents, as well.

\section{The Emergence of the Translated Poet}

The phenomenon of the translator poet has seen the light for the first time in the Arab culture of the 1950s, 1960s and 1970s. Translator poets, such as Adonis, Tawfiq Sayegh, Jabra Ibrahim Jabra, Yousef Al-Khal, Salma Al-Khadraa Al-Juyousi, Isam Mahfouz, Fouad Rifqa and from the later generation are Sarkon Polous, Abdulkader Al-Jenabi, Muhammad Bnais, Bassam Hajjjar, Abdo Wazen and Rifaat Salam, do not only write poetry, but they translate what enhances their creative choice or what poetry they like and admire. In 1955 Al-Sayyab has collected a number of poems that he had translated from a number of international poets and chose for them the title "Selected Poems from Modern International Poetry". This title included translated poetry of sixteen foreign poets, such as the Spanish Lorca, the American Ezra Pound, the Indian Tagore, the Turkish Nazim Hekmat, the Italian Giovanni, the British T.S. Eliot and Edith Sitwell and the Chilean Pablo Neruda. The second half of the twentieth century formed a special condition for the global culture in general and the Arab culture in particular. In this sense we mean the technical development and the end of the Second World War which was about to destroy life using atomic weapons. As a result, philosophies and different ways of life arose on the banks of the previous issues. Existentialism which was a response to the war and destruction has been developed, and the creators of this Philosophy started to ask many questions related to fate, destiny and the viability of civilisation, and all these ideas were translated into Arabic. Then, poetry turned into a field that assimilates what is presented of all philosophical and theological issues, sociology and anthropology in addition to politics, myth and history. (Saed, 1984: 31) The contemporary poet believed that he/she should participate in this clash among creators, politicians, warmakers and the sanctification of religious institutions, and he/she is entrusted with the mission of rescuing the world from evils and poetry is the vessel of this task. Poets believed that poetry must not resemble the poetry of transgressors. Hence, the poet found himself/herself under the influence of Randall Jarrell's saying: "The greatest betrayal a 
writer commits is to formulate the harsh truth in a cheap phrase."(Randall, 1963: 33) Although some poetry critics, starting from the 1950s supported the modernisation in Arabic poetry which was based on literacy with foreign poetry and a direct influence of it whether in terms of form or in terms of content and vision, they criticised in many occasions the ambiguity, the vagueness and the obscurity that modern poem sank into. So, the accumulation of culture, its multiplicity, diversity and depth in our modern era does not mean that the poet moves on in a horizon crowded with these cultures but means a semantic crowding in which there is ambiguity and multiplicity that afflict the recipient with confusion before the poetic text. The poet of modernity has found himself face to face with a river of knowledge flowing from multiple sources, and colourful tributaries in which the scientific, the superstitious, the historical, the mythological, religious philosophies, and all the colours of the era's knowledge are mixed. It is a truly strange epistemological combination and when the poetic text has been formed out of it and entered into its fabric, it increased the difficulty of reading it, complicated the process of receiving it, and expanded the ambiguity of its connotation. (al-Qoud. 2002: 24). For example, Adonis says:

I tied my ships to The wind

And delegated myself to the wanes

You burdensome, open your hands, look:

How empty They are!

How affectionate is this space is! (Adonis, 1999: 13090)

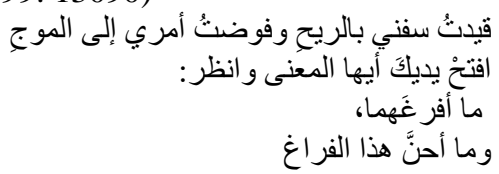

Mohammad Afifi Matar in his poem "doubts" says:

Voice:

O' my blind travel

In the alchemy mine and the last transformation

Ties of things dissolve in my blood

The disjointed elements dance

The branches turn over at the roots

The fruits of fire are plonked in the burning vine

Water in my blood kills my split seed

The air ignites, the ashes become pregnant

But, I am waiting for the last shift,

So as to, the darkened, burning mines

Take my hatred to the world of bitterness. (Matar, 1998: 34-35)

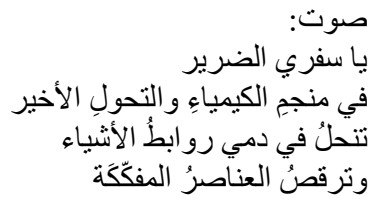




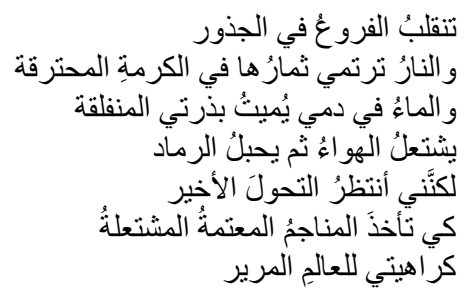

\section{The New Poetry Crisis}

The critics or poets had no longer strict critical norms that Control the state of chaos that affected the prosaic poetry compared to the strict and rigid norms which for instance existed in The rhythmic poetry and its rhythms. Then The Arabic poetry lacks The conceptual structure that governs it. A new battle of legitimacy starts asking what is the new poetry, the free poetry and the semi-rhythmic poetry that pioneers meant and these voices began to appear by the pioneers of new poetry and those who are enthusiastic about it. Nazik Al-Malaika in her book "The Issues of Modern Poetry" published in 1964, that's more than fifteen years after her first statement and her first poem written in free verse, says: "I am certain that the free-flow of poetry will come to an end in a day that's not far, and poets will return to the fully rhythmic poetry after they have gone out if their way and underestimated it. This doesn't mean that free poetry would die, but it would remain alive and poets would use it for some of their purposes and targets without becoming fanatic and leaving the rhythmic beautiful Arabic poetry. (al-Malaika, 1967: 48) Moving to Adonis' opinion which seems harsher than Nazik Al-Malaika's. He believes that this revolution against the classical methods had brought poetry into a new crisis which is the entry of any willing person into the field of poetry that once was really sacred and the Arabs linked it to ingenious Valley (Abkar Valley, the valley of inspiration, the imaginary home of poetry; fairyland). Adonis says: "The problem in the Arabic poetry now is no longer in the conflict between it and the classical one, but it has truly become in knowing and distinguishing the modern poetry indeed. In fact, the poetic output is full of confusion, chaos, petty vanity and almost illiteracy. Among the new poets are those who are ignorant of the most basic requirements of poetry in terms of awareness of the language secrets and the control over them, and those who don't know about poetry other than arranging the rhymes and poetic metres in a certain context and yet each of them fills up newspapers and magazines with superiority and precedence over others claiming that he/she is the prophet and the pioneer of modern poetry. Rather, we are with those who say that the modern poetry is full of magicians and clowns. (Adonis, 2005: 236-237) Dr. Ihsan Abbas, who was enthusiastic about modern poetry, presented early studies about modern poetry, one of them was published in 1955 and called "Abdulwahab Al-Bayati and modern Iraqi poetry". Dr. Ihsan Abbas believes that there are reasons outside the poetic process or the poetic text that contributed to not spread this poetry among people. One of these reasons is the song which still relies on alliteration and other creative rhetorical devices in terms of form. The song, which talks about desertion, observation, watchfulness, torment and tears in terms of content, seems disconnected from the transformation and change that has occurred in the society, looking at the emotional relationships. The school is another reason in which the teacher 
doesn't find in his hands a critical mean that would unlock the blockages in the modern poetic text and therefore a teacher finds himself more comfortable teaching classical models of poetry. Furthermore, poetry gatherings and festivals which adopted the rhetorical tone played a great role in detaining modern poet to spread among people. (Abbas, 1978: 21-22)

\section{E. Coexistence of the Two Species}

The Arabic rhythmic poem has retreated due to the sweeping current of the prosaic poem that was encouraged by cultural institutions. On the other hand, the classical poetry which based on rhythm and rhyme including both styles: rhythmic and semi-rhythmic remained present and the clear proof of that is the continued emergence of many poets, such as Nizar Qabbani, Al-Jawahiri and Omar Abu Risha, while the prosaic poem kept rising. Observers of the contemporary Arab poem's reality would find that the rhythmic poem has once again topped the scene and this is because of the inability of the prosaic poem to be apart of the people's culture and it remained isolated in its ivory tower as mentioned before. In addition, the prosaic poem didn't take into account that poetry is an important part of the Arabs' culture and they are still attached to the high classical models of poetry, such as The Mu'allaqat (The Hanging Poems; a set of ten long Arabic poems which were hung on in the Kaaba in Mecca and they are considered the primary source of early Arabic poetry; The Mu'allaqat used to be written in gold not ink), AlMutanabbi and Abu Tammam which were considered high-ranked, bright and pure poetry. At the beginning of the 1980s Nizar Qabbani versified his poem " $O$ ' Green Tunesia" which spread widely as fast as fire among people as if the crowd had a different word in defining the concept of poetry other than what was presented by the new poetry groups.

Nizar says:

O’ green Tunesia, I've come to you as a lover

On my forehead, a rose and a book

For I am the Damascene whose profession is passion

Whose sining turns the herbs green

I burnt behind all my boats

Passion is, not to be a return

Above the women's eyelids, into pieces I'm broken

Wood and waves are my age

Not forgetting women's names, but

Beauty has reasons, and I have mine. (Qabbani, 1985: 45)
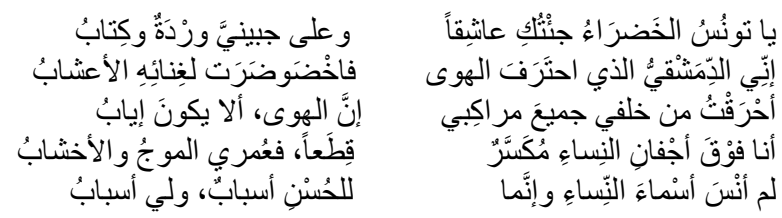
When Nizar finished that flirtatious introduction, he expressed his anger on the Arab political reality as if he wanted to say that the traditional form of the classical poem in its rhythmic line is still capable of carrying contemporary contexts and the poetry scene has become more balanced. That's to say that the rhythmic poetry has its audience and writers as well as the semi-rhythmic poetry which was later replaced by the prosaic poem. The matter remained as an open truth between the two tendencies with battles breaking out from time to time fighting for the legality, the essence and reasonableness of the prosaic poem.

\section{Conclusions and Results}

The Arabic poem has taken a harsh adventure by abandoning the concepts of traditional Arabic poetry and moving to the other bank with different concepts and visions which are fully brought from foreign poetry of all nationalities in spite of the big role and influence of the English and French poetry in particular. Hence, I say that this experience has developed a lot in the perceptions of poets, critics and people about the concept of saying despite its fall in a receipt crisis that was attacked by those who were suspicious of it and from the aim of this systematic neutralisation of the Arab poetry concepts and to introduce western concepts instead. To add, this is an evidence of flexibility and vitality that the Arabic language has a proof that it has an inner desire to experience, receive and cross-pollinate with other cultures. This is as well confirms the permanent idea of creative people who precede the critics in developing texts in term of form and content and they have a constant willingness, that's not strange, but inherited, to go through experiences no matter how sever they are. For instance, Abu Tammam and poets belong to Al-Shami Poetry School, such as Deek Al-Jinn Al-Humsi and Muslim Ibn Al-Walid have done that and experienced new tendencies in their poetry. Whereas conservative critics considered that they are disobedient and dared to review the poem's form and they way the image was constructed, and this something as you know was really shocking at that time.

\section{References}

Abbas, Ihsan. (1978). Ittticâhâtu'ş-Şi 'ri'l- 'Arabiyyi'l-Mu 'âsir. Knowledge World Series, 2nd Issue.

Adonis .(2005). The time of poetry . Dar Al -Saqi.

Adonis. (1999). Al Hayat Newspaper. Thursday,7th January, 13090.

Agina, Muhammad.(2001) .et-Tercemetu'l-Edebiyye. Rehab Al-Maarifa. 4(21) MayJune.

Al-Akkad, Abbas Mahmoud. (2013). Dîvânun min Devâvîn. Hindawi institution for culture and education.

Al-Jahiz. (1996) .Kitâb al-hayavân. study: Abdulsalam Haroon. Al-Jeel publisher.

Al-Jahiz.( wd) .el-Beyân ve^t-tebyîn. study: Abdulsalam Haroon. Al-Jeel Publisher. 
Horace. (1988). The Art of Poetry. translated: Louis Auad. The General Egyptian Book Organisation.

Luallwa, Abdulwahid. (1980). el-Ardu'l-Yebâb eş-Şâ 'iru ve'l-Kasîde. Arab Scientific Publishers.

Matar, Mohammad Afifi. (1998). el-A 'mâlu'ş-Şi 'riyyetu'l-Kâmile; Melâmihu fi'lVechi'l-Ambizoklîsî. Al-Shorouq Publisher.

Al-Malaika, Nazik .(1967) .Kadâya'ş-Şi 'ri'l-Mu 'âsir. Al-Nahda bookshop publishes.

Nazem, Hasan .(1994). Mefâhîmu'ş-Şi 'riyye; Dirâsetu Mukâranetin fîll-Usûli ve'lMenheci ve'l-Mefâhîm. The Arab Cultural Center.

Qabbani, Nizar.(1985). Kasâ'idu Mă̆dûbun 'Aleyhâ. Nizar Qabbani Publishing.

Al-Qoud, Abdulrahman. (2002) .el-İbhâmu fî Şi 'ri'l-Hadâse; el- 'avâmilu ve 'l-Mazâhiru ve Âliyyâtu't-Te'vîl. The Knowledge World Series.

Randall, Jarell .(1963). the Crisis of Contemporary Poetry. translated by: Maher Hasan Fehmi. Arab unity publisher for publishing, printing, distribution and advertising .

Ricoeur, Paul. (2008). About Translation. translated by: Hussein Khamri .Al-Ikhtelaf Publishing.

Saed, Khalida. (1984). el-Melâmihu'l-Fikriyyetu li'l-Hadâse. Fusoul magazine. 4(3)

Al-Sayyab, Bader Shaker. (2016). el-A 'mâlu'ş-Şi 'riyyetu'l-Kâmile. Dar Al-Auda.

Ib Sallam Al-Jumahi. (1994). Tabakât al-fuhûl al-şuara. study: Mahmoud Shaker. AlMadani Publisher. 